\title{
Pemetaan Lapisan Akuifer Formasi Makats Daerah Tanah Hitam Distrik Abepura Menggunakan Metode Geolistrik Tahanan Jenis
}

\author{
$\operatorname{Virman}^{1 *}$, Bagus Endar B. Nurhandoko ${ }^{2)}$ \\ ${ }^{1 *}$ Program Studi Pendidikan Fisika, PMIPA Uncen, Jl. Raya Sentani-Abepura \\ Jayapura \\ 2) Laboratorium Wave Inversion and Subsurfase Fluid Imaging Research \\ (Wisfir), Departemen Fisika ITB, \\ Jl. Ganesa 10 Bandung 40132 \\ virman_uncen@yahoo.com
}

\begin{abstract}
ABSTRAK
Air merupakan salah satu sumberdaya alam yang sangat besar nilainya bagi semua mahluk hidup. Bagi kehidupan manusia, air merupakan salah satu kebutuhan dasar seperti minum, masak, mandi, mencuci, air juga dibutuhkan dalam proses industri. Pada umumnya pemenuhan kebutuhan air dilakukan dengan pemanfaatan air tanah. Air tanah lebih terlindung dari polusi atau pencemaran dan penyebarannya tidak merata di bawah permukaan. Telah dilakukan penelitian yang bertujuan untuk memetakan lapisan akuifer di Daerah Tanah Hitam Distrik Abepura. Daerah penelitian memiliki topografi yang tidak datar dan secara geologi termasuk dalam formasi Makats. Formasi tersebut tersusun oleh batulanau dan batulempung, sisipan napal dan konglomerat. Bagian bawah dari formasi ini jenis batuannya berupa tuf dan breksi gunungapi. Kegiatan penelitian bertujuan untuk memetakan sebaran akuifer menggunkan metode geolistrik tahanan jenis, konfigurasi Schlumberger. Berdasakan hasil pengukuran dan intepretasi data geolistrik maka di Daerah Tanah Hitam Distrik Abepura lapisan akuifer berada pada kedalaman antara 40 hingga $60 \mathrm{~m}$. Hal ini didasarkan pada munculnya nilai tahanan jenis antara $4.34 \mathrm{ohm}$ hingga $30.1 \mathrm{ohm} \mathrm{m}$, akuifer yang berkembang berupa litologi pasir tufaan.
\end{abstract}

Kata kunci : air tanah, akuifer, tahanan jenis.

\begin{abstract}
Water is a natural resource of great value for all living creatures. For human life, water is one of the basic needs such as drinking, cooking, bathing, washing, water is also required in the process industry. In general meeting water needs to do with
\end{abstract}


the utilization of ground water. Groundwater is better protected from pollution or contamination and spread unevenly beneath the surface. Has conducted research that aims to map the aquifer layer in the Black Soil Region Abepura district. The research area has a flat topography and geology, including the formation Makats. The formation is composed of siltstone and claystone, marl and conglomerate inserts. The lower part of the formation of this type of rock in the form of tuff and volcanic breccias. The research activity aims to map the distribution of the aquifer using the method of geoelectric resistivity, Schlumberger configuration. Based on the measurement results and the geoelectric data interpretation in Black Soil Region Abepura district aquifer layer is at a depth of between 40 to $60 \mathrm{~m}$. It is based on the rise of the value of resistivity between $4: 34 \mathrm{ohm}$ to $30.1 \mathrm{ohm} \mathrm{m}$, aquifer that develops in the form of sand lithology tuff.

Keywords: ground water, aquifers, resistivity.

\section{Pendahuluan}

Air adalah sumber daya alam yang mutlak dibutuhkan oleh setiap makhluk hidup. Air bagi manusia terutama digunakan untuk minum, masak, mandi, mencuci, dan lebih dari itu air juga digunakan untuk menggerakkan industri, peternakan dan pertanian.

Data global yang dilansir oleh National Geographic menyebutkan bahwa dari total air di bumi $97.5 \%$ adalah air asin. Sementara itu, sisanya $2.5 \%$ adalah air tawar. Sebanyak $2 / 3 \%$ dari air tawar tersebut terdiri dari lapisan es, gletser, dan salju. Sisanya barulah air permukaan dan air tanah. Air tanah adalah air yang digunakan untuk mencukupi kebutahan kita. Tentu saja air tanah itu harus dipertahankan masa umurnya di tanah agar bisa tetap menjadi cadangan air untuk kehidupan kita. Sebaliknya, yang menyedot air tanah semakin berlebihan. Para penyedot air untuk kepentingan industri yang begitu boros air serta semakin merebaknya bisnis air bening dalam kemasan telah menyumbang semakin dalamnya muka air tanah.

Pemanfaatan air tanah merupakan upaya untuk memenuhi kebutuhan air di masa sekarang dan yang akan datang, serta merupakan alternatif yang terbaik apabila air di permukaan sudah tidak mencukupi atau terjangkau. Air tanah bebas dari penularan penyakit, lebih terlindung dari polusi atau pencemaran serta pengotoran lainnya. Sumber daya air tanah bersifat dapat di perbaharui (renewable) secara alami, karena air tanah merupakan bagian yang tidak terpisahkan dari siklus hidrologi di bumi.

Air tanah ditemukan pada formasi geologi tembus air yang dikenal dengan akuifer. Kedalaman akuifer disuatu daerah tidak sama dengan daerah lain, tergantung dari beberapa 
faktor diantaranya iklim/musim, vegetasi, topografi, porositas tanah dan permeabilitas (Supardi, 2005). Untuk mengetahui keberadaan lapisan akuifer perlu diketahui lapisan geologi bawah permukaan.

Saat ini telah diperkenalkan beberapa metode yang sering digunakan dalam penyelidikan lapisan geologi bawah permukaan yaitu metode pemboran dan beberapa metode geofisika. Metode geofisika sendiri merupakan metode yang sering digunakan pada tahap pendugaan lapisan geologi bawah permukaan. Salah satu metode geofisika yang banyak digunakan untuk mengetahui penyebaran lapisan akuifer adalah geolistrik tahanan jenis. Metode ini lebih praktis dan mudah dilakukan dibandingkan dengan beberapa metode geofisika lainnya.

Aplikasi metode geolistrik tahanan jenis untuk mengetahui kondisi di bawah permukaan bumi melibatkan pengukuran diatas permukaan bumi dari parameter-parameter fisika yang dimiliki oleh batuan di dalam bumi. Dari pengukuran ini dapat ditafsirkan bagaimana sifat-sifat dan kondisi dibawah permukaan bumi baik itu secara vertikal maupun lateral (Tulus, 2013).
Metode ini menggunakan asumsi bahwa bumi bersifat homogen isotropis. Dengan asumsi ini tahanan jenis yang terukur sebenarnya tidak bergantung pada spasi elektroda. Pada kenyataannya, bumi terdiri dari lapisan-lapisan dengan $\rho$ berbeda. Sehingga potensial yang terukur merupakan pengaruh dari lapisanlapisan tersebut. Oleh karena itu harga tahanan jenis yang diukur bukan merupakan nilai tahanan jenis untuk satu lapisan saja, hal ini terutama untuk spasi elektroda yang lebar. Harga tahanan jenis yang terukur tersebut disebut nilai tahanan jenis semu (apparent resistivity). Tahanan jenis semu dirumuskan sebagai (Loke, 2002):

$\rho_{a}=K \frac{\Delta V}{I} ; R=\frac{\Delta V}{I}$

Dimana $\rho_{a}$ adalah tahanan jenis semu, $\mathrm{K}$ adalah faktor geometri, $\Delta \mathrm{V}$ adalah beda potensial antara kedua elektroda potensial dan I adalah kuat arus yang diinjeksikan. Berdasarkan persamaan (1) dapat diketahui bahwa nilai tahanan jenis semu tergantung pada konfigurasi elektroda yang digunakan. Berdasarkan letak (konfigurasi) elektroda-elektroda 
arus dan potensialnya, dikenal $\mathrm{r}_{1}=$ jarak dari titik $\mathrm{P}_{1}$ ke sumber arus beberapa jenis konfigurasi antara lain positif (L-1)

konfigurasi Schlumberger, konfigurasi $\quad r_{2}=$ jarak dari titik $P_{1}$ ke sumber arus Wenner, konfigurasi dipole-dipole dll. negative $(\mathrm{L}+\mathrm{l})$

Dalam penelitian ini digunakan $r_{3}=$ jarak dari titik $\mathrm{P}_{2}$ ke sumber arus konfigurasi Schlumberger. Pengukuran positif $(L+1)$

dengan konfigurasi Schlumberger $\quad r_{4}=$ jarak dari titik $\mathrm{P}_{2}$ ke sumber arus seperti tampak pada Gambar 1 , negatif $(\mathrm{L}-1)$

menggunakan 4 elektroda, masingmasing 2 elektroda arus ( $\mathrm{C} 1$ dan $\mathrm{C} 2$ ) dan 2 elektroda potensial (P1 dan P2).

Untuk aturan elektroda Schlumberger, spasi elektroda arus jauh lebih lebar dari spasi elektroda potensial.

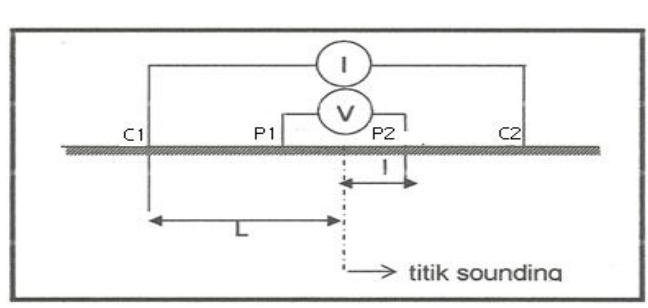

Gambar 1. Konfigurasi Schlumberger (Telford, 1990)

Berdasarkan persamaan (1) apabila diturunkan maka diperoleh tahanan jenis semu untuk konfigurasi Schlumberger sbb:

$\rho=2 \pi\left[\left(\frac{1}{r_{1}}-\frac{1}{r_{3}}\right)-\left(\frac{1}{r_{2}}-\frac{1}{r_{4}}\right)\right]^{-1} \frac{\Delta V}{I}$

Dimana:
Hal ini menghasilkan faktor geometri $(\mathrm{K})$ dan tahanan jenis semu untuk elektroda Schlumberger adalah (Telford, 1990):

$$
\begin{aligned}
& \rho_{S}=K_{S} \frac{\Delta V}{I} \quad \text {, dengan } \quad \mathrm{K}_{\mathrm{s}}= \\
& \frac{\pi\left(L^{2}-l^{2}\right)}{2 l}
\end{aligned}
$$

Setiap konfigurasi mempunyai penetrasi kedalaman yang tidak sama, sehingga dalam pengukuran penetrasi kedalaman merupakan salah satu faktor yang menjadi pertimbangan dalam pemilihan konfigurasi elektroda, faktor lain adalah jenis struktur, sensitivitas alat, tingkat nois yang ada. 
2. METODOLOGI

PENELITIAN

\subsection{Lokasi Penelitian}

Lokasi penelitian (Gambar 2) berada di Daerah Tanah Hitam, secara geografis terlatak pada S: 02 33' 47.9" dan E: 140 41' 42.9" dan secara administratif termasuk Distrik Abepura Kota Jayapura. Berdasarkan Gambar 2 tersebut topografi daerah penelitian yang tidak datar tepatnya berada di lereng barisan Pegunungan Cycloop bagian selatan.

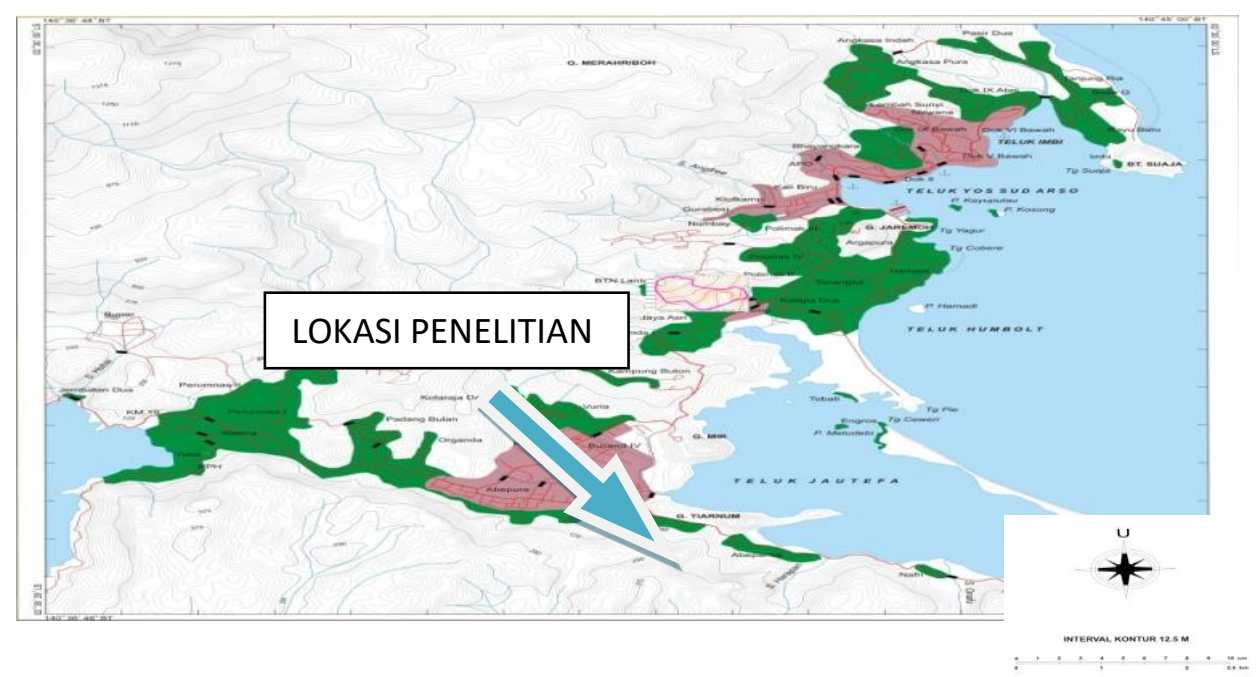

Gambar 2 Lokasi Penelitian

\subsection{Peralatan}

Peralatan yang digunakan dalam penelitian ini adalah GPS Garmin Vista, rollmeter, Geolistrik Merk Noniura NRD 328 HF. Beberapa alat penunjang yang diperlukan adalah:

- $\quad$ Accu, sebagai sumber arus listrik yang dihubungkan ke alat Noniura NRD 328 HF.

- Elektroda terbuat dari tembaga, merupakan komponen yang menghubungkan antara alat dengan permukaan tanah, terdiri atas dua elektroda arus dan dua elektroda potensial.

Kabel penghubung antara alat dengan elektroda

Jumlah lintasan maupun titik pengukuran ditentukan setelah dilakukan survei lokasi. Berdasarkan survei yang dilakukan maka ditetapkan sebanyak tiga lintasan pengukuran 
masing-masing di Aspol Abepura, Rumah Sakit Umum Abepura dan Jalan Pasar Youtefa.

\subsection{Akuisisi Data}

Akuisisi data dilakukan dengan injeksi arus melalui dua elektroda arus dan beda potensial yang timbul dapat diamati melalui dua elektroda potensial. Injeksi arus dilakukan melalui susunan elektroda dalam konfigurasi Schlumberger (Gambar 1). Pasangan elektroda arus $(\mathrm{C} 1, \mathrm{C} 2)$ disusun dengan jarak yang lebih besar dibandingkan dengan pasangan elektroda (P1,P2). Jarak antar pasangan elektroda arus diperbesar untuk mengukur nilai tahanan jenis yang lebih dalam. Saat beda potensial mulai sulit terbaca/terukur, sensitivitas alat berkurang sehingga jarak antar pasangan elektroda potensial harus diperbesar. Besarnya arus listrik dan beda potensial untuk masing-masing elektroda arus dan elektroda potensial dicatat untuk menghitung nilai tahanan jenis semu dari material penyusun lokasi penelitian.

\subsection{Pengolahan Data}

Data yang diperoleh berupa beda potensial (volt) dan arus (mA), data hasil pengukuran tersebut kemudian disubtitusikan kedalam persamaan (2) untuk mendapatkan nilai tahanan jenis semunya. Data tahanan jenis semu tersebut diolah atau diinversi dengan persamaan matematis untuk mendapatkan nilai tahanan jenis sebenarnya. Dalam penelitian ini input data tahanan jenis semu diolah dengan menggunakan perangkat lunak IPI2WIN. Dalam metode geolistrik tahanan jenis pengolahan data bertujuan untuk memperoleh banyaknya lapisan, harga tahanan jenis, serta ketebalan masing-masing lapisan. Software IPI2win ini akan memberikan kriteria cocok antara data lapangan dengan respon model masukan atau RMS Error.

\subsection{Intepretasi Data}

Hasil intepretasi semua titik amat kemudian dibuat penampang, sehingga diperoleh gambaran kondisi lapisan air bawah permukaan di daerah penelitian. Intepretasi/analisis data didasarkan 
pada nilai tahanan jenis batuan bawah permukaan. Tahanan jenis merupakan parameter penting untuk mengkarakterisasi keadaan fisis bawah permukaan. Parameter tersebut bergantung pada litologi, sesar, porositas, suhu, tekanan, fluida yang mengisi batuan, Sutarno (1993). Parameter-parameter tersebut dapat menaikkan dan menurunkan tahanan jenis. Pori batuan yang terisi air akan memperlebar jangkauan nilai tahanan jenis batuan, Schon (1998). Untuk menentukan ada tidaknya lapisan aquifer, letak maupun ketebalan maka diperlukan beberapa data pendukung diantaranya yaitu data singkapan maupun sumur penduduk serta data geologi regional daerah tersebut.

\section{HASIL DAN PEMBAHASAN}

\subsection{Geologi Daerah Penelitian}

Geologi daerah penelitian batuannya tersusun dari formasi Makats, jenis batuannya berupa grawcke, dibeberapa tempat berselingan dengan batulanau dan batugamping, sisipan napal dan lensa batugamping. Di bagian bawah bersisipan tufa dan breksi gunungapi.

Umumnya kelulusannya sedang sampai rendah.

Geomorfologi atau kondisi topografi didominasi oleh pegunungan dan perbukitan yang merupakan bagian dari pegunungan Cycloop dan telah ditetapkan sebagai kawasan cagar alam setempat. Geomorfologi Daerah Tanah Hitam, terutama wilayah bagian utara pada dasarnya adalah morfologi lereng kaki gunung Cycloop. Merupakan wilayah dengan kemiringan sekitar 3\% sampai $6 \%$, sebagian besar wilayahnya telah menjadi daerah pemukiman penduduk, kantor pemerintah dan swasta, hotel dll.

Kabupaten Jayapura dan sekitarnya beriklim tropis basah yang rata-rata curah hujan setiap bulan lebih dari $200 \mathrm{~mm}$ atau curah hujan rata-rata pertahun sekitarnya sekitar $3.276 \mathrm{~mm}$. Pegunungan Cycloop yang terdapat di bagian timur Kabupaten Jayapura dianggap sebagai sumber penyebab curah hujan di daerah ini. Pada bulan Desember sampai bulan April terjadi musim angin yang bertiup dari arah barat laut dan membawa uap air dari 
Samudra Pasifik selanjutnya akan berupa dataran rendah, sumber air berubah menjadi hujan. dapat dijumpai pada kedalaman antara

Danau Sentani mendapatkan suplai dari sekitar \pm 34 sumber mata air dari pegunungan Cycloop. Sumber air danau ini berasal dari 14 sungai besar dan kecil. Luas daerah tangkapan air danau sekitar $600 \mathrm{~km}^{2}$. Ada satu muara yaitu Sungai Djaifuri yang terletak di sebelah Timur (daerah Puay). Beberapa inlet Danau Sentani yaitu Sungai Belo, Sungai Flafouw, dan Sungai Harapan.

Airtanah dan sistem akuifer, berdasarkan berbagai publikasi terdahulu, peta hidrogeologi, sistem akuifer yang berkembang di daerah penelitian umumnya yang berfungsi sebagai akuifer adalah batuan-batuan vulkanik maupun endapan aluvial yang berumur Kuarter. Sedangkan jenis akuifer berdasarkan topografi yang berkembang dan dimungkinkan diekploitasi airtanahnya adalah akuifer tertekan dan akuifer tak tertekan. Akuifer tertekan umumnya dijumpai 3 hingga 10 meter.

\subsection{Hasil Pengukuran Geolistrik} Tahanan Jenis

Menurut Telford

tahanan jenis suatu batuan atau lapisan batuan mempunyai batas berkisar $10^{-6}$ ohm $\mathrm{m}$ hingga $10^{12} \mathrm{ohm} \mathrm{m}$, rang yang cukup besar ini antara lain disebabkan oleh kondisi geologi. Rang tahanan jenis yang cukup besar ini akan menimbulkan penafsiran yang berbeda pada nilai tahanan jenis tertentu, dalam geofisika hal ini dikenal dengan istilah ambiguitas. Inilah salah satu alasan sehingga dikatakan metode geofisika hasilnya bersifat prediksi atau pendugaan. Agar pendugaan yang dilakukan mendekati yang sebenarnya maka dalam intepretasi data geolistrik digunakan tahanan jenis standar (referensi). Dalam penelitian ini tahanan jenis referensi yang digunakan seperti pada Tabel 1.

pada bagian selatan dimana topografi berupa perbukitan. Sedangkan akuifer tak tertekan terdapat di bagian utara daerah penelitian dimana topografinya 
Tabel 1. Litologi dan Harga Tahanan Jenisnya (Fivry, 2013)

\begin{tabular}{lc}
\hline \multicolumn{1}{c}{ Litologi/Batuan } & Tahanan jenis (ohm m) \\
\hline Serpih terkonsolidasi & $20-2 \times 10^{3}$ \\
\hline Batupasir & $1-6.4 \times 10^{4}$ \\
\hline Konglomerat & $2 \times 10^{3}-10^{4}$ \\
\hline Batugamping & $50-107$ \\
\hline Dolomit & $3.5-10^{2}$ \\
\hline Lempung & $1-100$ \\
\hline Napal & $3-70$ \\
\hline Aluvial \& pasir & $4-800$ \\
\hline
\end{tabular}

Hasil pengolahan menggunakan IPI2win diperoleh berupa grafik, dan ketebalan lapisan batuannya beserta nilai tahanan jenis sebenarnya. Tabel 2 adalah data hasil pendugaan geolistrik Daerah Tanah Hitam, Distrik Abepura Kota Jayapura di tiga titik yaitu: 1. Titik duga 1 (Asrama Polisi Abepura), menggunakan panjang bentangan
$(\mathrm{AB} / 2) \quad 150$ meter dengan arah bentangan timur-barat. 2. Titik duga 2 (Rumah Sakit Umum Abepura), menggunakan panjang bentangan $(\mathrm{AB} / 2) 125$ meter dengan arah bentangan timur-barat. 3. Titik duga 3 (Jl. Pasar Youtefa), menggunakan panjang bentangan $(\mathrm{AB} / 2) 150$ meter dengan arah bentangan timur-barat. 
Tabel 2. Nilai tahanan jenis sebenarnya terhadap tiga titik duga

\begin{tabular}{|c|c|c|c|c|c|}
\hline \multirow{2}{*}{$\begin{array}{l}\text { Titik } \\
\text { Duga }\end{array}$} & \multirow[b]{2}{*}{ Lapisan } & \multicolumn{3}{|c|}{ Hasil Penafsiran } & \multirow[b]{2}{*}{$\begin{array}{l}\text { Perkiraan } \\
\text { Litologi }\end{array}$} \\
\hline & & $\begin{array}{l}\text { Kedalaman } \\
\text { (m) }\end{array}$ & $\begin{array}{l}\text { Ketebalan } \\
\text { (m) }\end{array}$ & $\begin{array}{c}\text { Tahanan } \\
\text { Jenis (ohm } \\
\text { m) }\end{array}$ & \\
\hline \multirow{5}{*}{1} & 1 & $0-0.75$ & 0.75 & 79.6 & Tanah penutup \\
\hline & 2 & 3.003 & 2.25 & 33.9 & $\begin{array}{c}\text { Pasir } \\
\text { berlempung }\end{array}$ \\
\hline & 3 & 13.47 & 10.5 & 17.1 & $\begin{array}{c}\text { Lempung } \\
\text { pasiran }\end{array}$ \\
\hline & 4 & 50.18 & 36.7 & 4.34 & Lempung \\
\hline & 5 & $>50$ & $\sim$ & 73.4 & pasir \\
\hline \multirow{4}{*}{2} & 1 & 1.03 & 1.03 & 1807 & Tanah penutup \\
\hline & 2 & 7.92 & 6.88 & 15.4 & lempung \\
\hline & 3 & 40.6 & 32.7 & 741 & konglomerat \\
\hline & 4 & $>40.6$ & $\sim$ & 30.1 & pasir \\
\hline \multirow{5}{*}{3} & 1 & 1.67 & 1.67 & 24.5 & Tanah penutup \\
\hline & 2 & 4.08 & 2.42 & 2.45 & lempung \\
\hline & 3 & 11.4 & 7.28 & 309 & konglomerat \\
\hline & 4 & 60 & 48.6 & 562 & $\begin{array}{c}\text { Konglomerat, } \\
\text { breksi }\end{array}$ \\
\hline & 5 & $>60$ & $\sim$ & 19 & pasir \\
\hline
\end{tabular}

Intepretasi data geolistrik pada penelitian ini memanfaatkan beberapa data pendukung seperti Peta Geologi Lembar Jayapura Skala 1:250.000 dan Peta Hidrologi lembar Jayapura Skala 1:100.000. Selanjutnya data pendukung tersebut dikorelasi dengan nilai tahanan jenis referensi (Tabel 1), hasil intepretasi seperti pada Tabel 2.

Berdasarkan Tabel 2 maka Daerah Tanah Hitam Distrik Abepura diduga terdapat confined aquifer atau akuifer tertekan. Akuifer tertekan ini terlihat jelas, pada titik duga 1 terdapat pada lapisan 5, titik 
duga 2 terdapat lapisan 4 dan titik duga 3 terdapat lapisan 5. Posisi akuifer tertekan yang terdapat di daerah Tanah Hitam penyebarannya mengikuti model morfologi permukaan. Dimana pengukuran di titik duga 2 terletak lebih rendah dibanding dua titik duga lainnya yaitu titik duga 1 dan titik duga 3 . Lapisan impermeabel berdasarkan nilai tahanan jenis, untuk titik duga 1 dan titik duga 3 berupa konglomerat atau breksi sedangkan untuk titik duga 2 berupa material berukuran lempung.

Akuifer yang terdapat pada ketiga titik duga adalah akuifer dengan material pasir. Akuifer ini ditemukan pada kedalaman bervariasi yaitu diatas $40 \mathrm{~m}, 50 \mathrm{~m}$ dan $60 \mathrm{~m}$ dari atas permukaan dan material dasarnya berupa alluvial. Berdasarkan beda tinggi akuifer tersebut dalam penelitian ini, dapat dikatakan bahwa air tanah bersifat dinamis dan arah aliran dari selatan ke utara. Dimana bagian utara daerah penelitian merupakan daerah lembah sedangkan bagian utara berupa barisan Pegunungan Cycloop. Zona Pegunungan Cycloop bagian selatan, ditinjau dari sisi geologi dan topografi termasuk dalam wilayah tangkapan air hujan (Cathment Area) yang mensuplai sistem aliran dengan topografi lebih rendah.

\section{Simpulan}

Penelitian geolistrik tahanan jenis metode Schlumberger di Tanah Hitam Distrik Abepura memperoleh gambaran jenis batuan yang ada, yaitu tanah penutup (top soil) berupa fragmen-fragmen alluvial, lempung atau lempung pasiran, breksi andesit dan batu pasir Hasil penelitian geolistrik terditeksi adanya anomali rendah yaitu antara 19 - 74 ohm m, diprediksi sebagai lapisan aquifer (mengandung air) di kedalaman yang bervariasi yaitu 40 meter, 50 dan 60 meter. Akuifer yang dijumpai di daerah penelitian ada yang bersifat dalam dengan kedalaman antara 40-60 meter terdapat di bagian selatan. Sedangkan akuifer dangkal berada pada kedalaman antara 3 hingga 10 meter terdapat di bagian utara dan merupakan dataran rendah

\section{Referensi}

1.

2. Agung, R., 2004. Informasi deteksi sumberdaya air tanah antara sungai Progo-Serang, Kabupaten Kulon Progo dengan metode geolistrik. Jurnal Teknik Lingkungan

P3TL-BPPT. Halaman 48-55. 
3. Fivry, W. M., 2013. Potensi akuifer daerah Desa Karangmojo Kecamatan Weru Kabupaten Sukuharjo Propinsi Jawa Tengah berdasarkan data geolistrik. Jurnal Teknologi Technoscientia. Hal. 55-64.

4. Loke, M.H., 2002. Electrical imaging survey for engineering studies, diakses melalui http://www.geometrics.com pada 06 November 2016

5. Schon, J. H., 1998. Physical properties of rock: Fundamental and principles of Petrophysics, Pergamon, Leoben.

6. Sutarno, D., 1993. Metode magnetotellurik, Teori dan Aplikasinya, J. Kontribusi Fisika, 4, 333-352.

7. Supardi. 2005. Pengelolaan air permukaan di Wonoharjo Kabupaten Karanganyar. Jurnal Keairan. Halaman 64-70

8. Telford, W. M., Geldart, L. P., dan Sherif, R. E., 1990. Applied Geophysics, Cambridge University Press, New York.

9. Tulus, P., Supriyadi, dan Sulhadi. 2013. Aplikasi metode geolistrik dalam survei hidrotermal (studi kasus sumber air panas Ngilimut Gonoharjo Gunung Ungaran). Seminar Nasional Fisika Universitas Negeri Jakarta. 116-119. 